\title{
Assessment of hydro-geochemistry and groundwater quality of Rajshahi City in Bangladesh
}

\author{
M. G. Mostafa ${ }^{1}$ (I) S. M. Helal Uddin ${ }^{1}$ - A. B. M. H. Haque ${ }^{2}$
}

Received: 9 June 2015/Accepted: 2 October 2017/Published online: 23 October 2017

(c) The Author(s) 2017. This article is an open access publication

\begin{abstract}
The study was carried out to understand the hydro-geochemistry and ground water quality in the Rajshahi City of Bangladesh. A total of 240 groundwater samples were collected in 2 years, i.e., 2009 and 2010 covering the pre-monsoon, monsoon and post-monsoon seasons. Aquifer soil samples were collected from 30 locations during the monsoon in 2000. All the samples were analyzed for various physicochemical parameters according to standard methods of analysis, these includes $\mathrm{pH}$, electrical conductivity, total dissolved solids, total hardness, and total alkalinity, major cations such as $\mathrm{Na}^{+}$, $\mathrm{K}^{+}, \mathrm{Ca}^{2+}, \mathrm{Mg}^{2+}$, and $\mathrm{Fe}^{2+}$, major anions such as $\mathrm{HCO}_{3}^{-}$, $\mathrm{NO}_{3}{ }^{-}, \mathrm{Cl}^{-}$, and $\mathrm{SO}_{4}{ }^{2-}$ and heavy metals such as $\mathrm{Mn}, \mathrm{Zn}$, $\mathrm{Cu}, \mathrm{As}, \mathrm{Cd}$ and $\mathrm{Pb}$. The results illustrated that the groundwater was slightly acidic to neutral in nature, total hardness observed in all samples fall under the hard to a very hard category. The bicarbonate and calcium concentration in the groundwater exceeded the permissible limits may be due to the dissolution of calcite. The concentration of calcium, iron, manganese, arsenic and lead were far above the permissible limit in most of the shallow tube well samples. The study found that the major hydrochemical facies was identified to be calcium-bicarbonate-type $\left(\mathrm{CaHCO}_{3}\right)$. A higher concentration of metals including Fe, $\mathrm{Mn}, \mathrm{As}$ and $\mathrm{Pb}$ was found indicating various health hazards. The rock-water interaction was the major geochemical process controlling the chemistry of groundwater in the
\end{abstract}

M. G. Mostafa

mostafa_ies@yahoo.com

1 Institute of Environmental Science, University of Rajshahi, Rajshahi 6205, Bangladesh

2 Department of Chemistry, University of Rajshahi, Rajshahi, Bangladesh study area. The study results revealed that the quality of the groundwater in Rajshahi City area was of great concern and not suitable for human consumption without adequate treatment.

Keywords Physicochemical - Groundwater . Geochemistry · Rajshahi City Tube well

\section{Introduction}

Recently, the provision of safe drinking water remains a major target for both the developed and developing countries. In the past three decades, excessive installation of rural groundwater supplies through tube wells have led to increasing contamination in groundwater. A detailed geochemical study of groundwater is used to understand the role of various elements in groundwater aquifer, including all the major ions such as $\mathrm{Na}, \mathrm{K}, \mathrm{Ca}, \mathrm{Mg}, \mathrm{Fe}, \mathrm{Mn}, \mathrm{Zn}, \mathrm{Cu}$, $\mathrm{Pb}, \mathrm{As}, \mathrm{Cd}$ and how the elemental fluxes are exchanged through atmospheric, terrestrial and aquatic interactions. Geochemical studies of groundwater provide a better understanding of possible changes in quality as development progress (Sreedevi 2004; Jalali 2006; Subba Rao 2006; Gupta et al. 2009). In the past three decades, excessive installation of rural groundwater supplies through tube wells have led to increasing contamination in groundwater of Bangladesh. Geochemistry is the science that uses the tools and principles of chemistry to explain the mechanisms behind major geological systems such as the Earth's crust and its oceans (Albarède and Francis 2003). Geochemistry of groundwater is an important factor in determining its use for various purposes such as domestic, irrigation and industrial uses. It depends on a number of factors, such as general geology, the degree of 
chemical weathering of various rock types, quality of recharge water and inputs from sources of other than water-rock interaction (Hem 1986). The geochemistry is the science that uses the tools and principles of chemistry to explain the mechanisms behind major geological systems such as the Earth's crust and its oceans (Albarède and Francis 2003). Geochemistry of groundwater is an important factor in determining its use for various purposes such as domestic, irrigation and industrial uses. It depends on a number of factors, such as general geology, the degree of chemical weathering of various rock types, quality of recharge water and inputs from sources of other than water-rock interaction (Hem 1986). In the past three decades, excessive installation of rural groundwater supplies through tube wells have led to increasing contamination in groundwater of Bangladesh.

Geochemical process, occurring within the groundwater and their reactions with the aquifer materials, are responsible for changes in groundwater chemistry and quality (Drever 1988; Hem 1991; Subba Rao and Surya Rao 2009). Therefore, it is impossible to control the dissolution of undesirable constituents in the waters once they enter into the ground (Johnson 1979; Sastri 1994). Many naturally occurring major, minor and trace elements in drinking water can have a significant effect on human health either through deficiency or excessive intake (Frengstad et al. 2001). Therefore, the fundamental knowledge of process control of groundwater chemistry is a pre-requisite condition for rational management of water resources. Groundwater is an important natural resource for domestic, industrial, commercial and irrigation purpose in Bangladesh. Safe drinking water is absolutely essential for healthy living. About $96 \%$ of the total population in Bangladesh has access to drinking water from tubewells (WHO Regional Office for South-East Asia 2002). It is the single largest source of drinking water in most of the developing countries and estimated that approximately one-third of the world's population is depending on groundwater where the general assumption of groundwater is being safe to drink (Nickson et al. 2005). Report (2015) showed that about $87 \%$ of the population had access to "improved water" there were still around 21 million lacking access to "improved" water in Bangladesh (Wikipedia 2015). It is perceived to be a safer source of drinking water with adequate protection and excellent microbial and chemical quality that requires minimum treatment. Groundwater resources in arid and semi-arid regions play a vital role on the socioeconomic development.

A few reports were found in the study area mainly confining in analysis and arsenic contamination of groundwater. An understanding of geochemical evaluation of groundwater is important for a sustainable development of groundwater resources in the study area that few researches have been conducted with the aim of assessing the chemical components of groundwater and limited information exists on vulnerability of the aquifer to pollution in Rajshahi City. Thus, a comprehensive study on hydro-geochemistry and groundwater quality assessment in the study area is imperative. The objective of this study is to determine the hydro-geochemical process controlling the water quality variations and to determine the water type of the groundwater to ascertain the suitability of water for drinking purposes.

\section{Materials and methods}

\section{Study area}

The study area was Rajshahi City in Bangladesh, which is the divisional headquarter as well as the administrative district (Fig. 1). It lies between latitudes $24^{\circ} 21^{\prime} \mathrm{N}$ and $24^{\circ} 25^{\prime} \mathrm{N}$ and longitudes $88^{\circ} 32^{\prime}$ and $88^{\circ} 40^{\prime}$ east. Rajshahi City is located in the north-west of the country with a population of about 646,716 (male $52.4 \%$, female $47.6 \%$ ). According to the Population Census 2001, the city has a density of 6689 people per $\mathrm{km}^{2}$ (Banglapedia 2006). It consists of 30 wards with a total area of $93.47 \mathrm{~km}^{2}$ and is situated on the northern banks of the river Padma (the downstream of the Ganges River in India). The climate of the city is generally marked by monsoons, high temperature, considerable humidity and moderate rainfall. It has a mean annual rainfall of below $1524 \mathrm{~mm}$ compared to a national average of $2540 \mathrm{~mm}$ (BBS 2005).

\section{Sample collection, preparation and analysis}

A total of 30 soil samples were collected at various depths (10-45 m) during borehole drilling in 2010 and stored in plastic bags and transported to the laboratory for physical and chemical analysis. $0.5 \mathrm{~g}$ of dry soil sample was weighed and poured into a graduated test tube and mixed with $2 \mathrm{~mL}$ of aqua regia 1:3 (1 Conc. $\mathrm{HCl}: 3$ Conc. HNO3) for the major heavy metals analysis such as $\mathrm{Fe}, \mathrm{Cu}, \mathrm{Zn}, \mathrm{As}$, $\mathrm{Cd}$ and $\mathrm{Pb}$. The mixture was digested on a hot plate at $95{ }^{\circ} \mathrm{C}$ for $1 \mathrm{~h}$ and allowed to cool at room temperature. The sample was then diluted to $10 \mathrm{~mL}$ using double distilled water and allowed to settle overnight. The supernatant was filtered and analyzed using AAS as stated by Adams (1991). 240 Representatives groundwater samples, of them 180 shallow tube wells and 60 deep tube wells samples were collected from 40 locations in Rajshahi City during the pre-monsoon, monsoon and post-monsoon season covering 2 years to evaluate the seasonal variations in chemical compositions and assess water quality. The samples were collected in $1 \mathrm{~L}$ plastic bottles, labeled, 
Fig. 1 Map of Locations of tube well water samples in Rajshahi City area

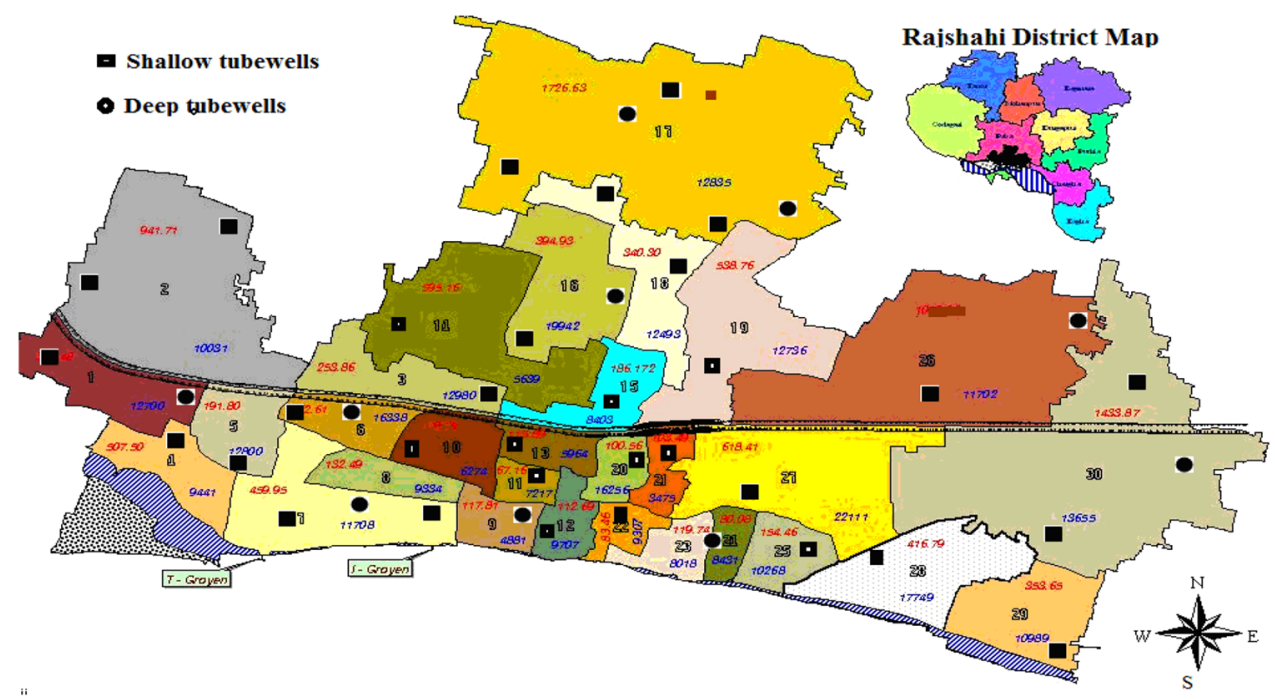

sealed and transported to the laboratory and stored in a refrigerator at a temperature of about $4{ }^{\circ} \mathrm{C}$ until the analysis was done. All the samples were analyzed according to the standard procedures as stated in American Public Health Association (APHA 2005). For microbial analysis, samples were collected in $250 \mathrm{~mL}$ glass bottles. All analyses were conducted in triplicate to ensure accuracy and precision. All reagents used in this study were analytical grade chemicals.

\section{Results and discussion}

The minerals characteristic of groundwater derives from reactions between rainwater and the host rock over a time scale of days, months, or years during percolation. The current study focused on the factors controlling the groundwater composition, soil chemistry and water type in the Rajshahi City area aquifer system.

\section{Physicochemical parameters of aquifer soil}

Physicochemical characteristics of shallow aquifer soil samples collected during the monsoon in 2010 are shown in Table 1. The maximum, minimum and mean values of electrical conductivity of the samples were 2928, 1040 and $1800.18 \mu \mathrm{S} / \mathrm{cm}$ indicating the presence of a moderate amount of ions (Table 1). The concentration of $\mathrm{Ca}$ was found to be highest $(220 \mathrm{mg} / \mathrm{L})$ in shallow aquifers as compared to other cations, where $\mathrm{Cd}$ concentration was the lowest $(0.02 \mathrm{mg} / \mathrm{L})$ indicating $\mathrm{Ca}$ dominance in aquifer soil (Table 1). Among anions, $\mathrm{HCO}_{3}{ }^{-}$and $\mathrm{NO}_{3}{ }^{-}$showed the highest and lowest concentrations and the values were 580 and $3.87 \mathrm{mg} / \mathrm{kg}$, respectively (Table 1 ). The mean concentration of $\mathrm{Zn}, \mathrm{Cu}$, As and $\mathrm{Cd}$ were consistently low at
Table 1 Characteristics of shallow aquifer soil samples during monsoon season in 2010

\begin{tabular}{lrcl}
\hline Parameter & Minimum & Maximum & Mean \pm SD \\
\hline $\mathrm{EC}(\mu \mathrm{S} / \mathrm{cm})$ & 1040.0 & 2928.0 & $1800 \pm 461$ \\
$\mathrm{HCO}_{3}{ }^{-}(\mathrm{mg} / \mathrm{kg})$ & 187.3 & 580.0 & $325.5 \pm 97$ \\
$\mathrm{Cl}^{-}(\mathrm{mg} / \mathrm{kg})$ & 36.04 & 121.78 & $76.8 \pm 19.5$ \\
$\mathrm{NO}_{3}{ }^{-}(\mathrm{mg} / \mathrm{kg})$ & 3.87 & 13.65 & $8.74 \pm 2.5$ \\
$\mathrm{SO}_{4}{ }^{2-}(\mathrm{mg} / \mathrm{kg})$ & 38.73 & 89.60 & $55.2 \pm 11.1$ \\
$\mathrm{Na}(\mathrm{mg} / \mathrm{kg})$ & 38.76 & 81.01 & $54.9 \pm 10.0$ \\
$\mathrm{~K}(\mathrm{mg} / \mathrm{kg})$ & 7.23 & 20.44 & $13.5 \pm 4.2$ \\
$\mathrm{Mg}(\mathrm{mg} / \mathrm{kg})$ & 6.39 & 166.80 & $86.8 \pm 34.9$ \\
$\mathrm{Ca}(\mathrm{mg} / \mathrm{kg})$ & 109.36 & 220.00 & $166.1 \pm 30.3$ \\
$\mathrm{Fe}(\mathrm{mg} / \mathrm{kg})$ & 5.93 & 11.86 & $8.79 \pm 1.64$ \\
$\mathrm{Mn}(\mathrm{mg} / \mathrm{kg})$ & 2.20 & 11.43 & $6.35 \pm 2.46$ \\
$\mathrm{Zn}(\mathrm{mg} / \mathrm{kg})$ & 0.08 & 1.600 & $0.76 \pm 0.40$ \\
$\mathrm{Cu}(\mathrm{mg} / \mathrm{kg})$ & 0.12 & 1.60 & $0.75 \pm 0.40$ \\
$\mathrm{As}(\mathrm{mg} / \mathrm{kg})$ & 0.05 & 0.85 & $0.32 \pm 0.24$ \\
$\mathrm{Cd}(\mathrm{mg} / \mathrm{kg})$ & 0.02 & 0.38 & 0.13 \\
$\mathrm{~Pb}(\mathrm{mg} / \mathrm{kg})$ & 0.09 & 4.01 & 0.73 \\
\hline
\end{tabular}

all samples compared to the rest of the heavy metal ions. A report showed that the mean values of $\mathrm{Zn}, \mathrm{Cu}, \mathrm{Cd}$ and $\mathrm{Pb}$ were found to be $60,30,0.15$ and $15 \mathrm{mg} / \mathrm{kg}$ in the Puebla aquifer system in Mexico (Jaime Gárfias and Arroyo 2010) and these values were far above compared to the present study results, except $\mathrm{Cd}$ concentration.

The analysis results showed that the mean concentration of cations and anions were observed in the order: $\mathrm{Ca}^{2+}>\mathrm{Mg}^{2}+>\mathrm{Na}^{+}>\mathrm{K}^{+}>\mathrm{Fe}^{3+}>\mathrm{Mn}^{2+}>\mathrm{Pb}^{2+}>\mathrm{Zn}^{2+}$ $>\mathrm{Cu}^{2+}>\mathrm{As}$ (total) $>\mathrm{Cd}^{2+}$ and $\mathrm{HCO}_{3}{ }^{-}>\mathrm{Cl}^{-}>$ $\mathrm{SO}_{4}{ }^{2-}>\mathrm{NO}_{3}{ }^{-}$, respectively (Table 1). It is well established that natural metal loadings to groundwater reflect the 
chemical composition of local bedrock (Piispanen and Nykyri 1997; Loukola-Ruskeeniemi et al. 1998, 2003). In general, water composition mostly depends on the aquifer soil with rainwater pattern reaction condition.

\section{Physicochemical and microbial parameters of groundwater}

The mean and standard deviation of water quality parameters of shallow and deep tube wells during the pre-monsoon, monsoon and post-monsoon seasons in Rajshahi City are shown in Table 2.

The mean temperature of shallow and deep tube wells water samples measured 27.39 and $27.187{ }^{\circ} \mathrm{C}$, respectively (Table 2). The results showed that a small variation in temperature was observed to be in both the shallow and deep tube wells water collected in three seasons (not shown in Table 2) due to temperature variations of the earth. The $\mathrm{pH}$ of the shallow and deep tube wells water samples was with a mean of 6.90 and 6.98 , respectively. Most of the groundwater samples $\mathrm{pH}$ were within the permissible limit as prescribed by WHO (2008) and Bangladesh drinking standard (2003). The results of this study indicate that the water was slightly acidic to neutral $\mathrm{pH}$. Though $\mathrm{pH}$ has no direct effect on human health, it shows close relations with some other chemical constituents of water (Pitt et al. 1999).

Electrical conductivity (EC) values signify the amount of total dissolved salts and indicate the inorganic pollution strength of water. Water conductivity in the study area in shallow and deep tube wells water sample was found to be 445.44 and $454.98 \mu \mathrm{S} / \mathrm{cm}$, respectively (Table 2). EC values of all the samples were bellowed the standard value $(1500 \mu \mathrm{S} / \mathrm{cm})$ of WHO.

TDS of shallow and deep tube wells were 257.43 and $241.65 \mathrm{mg} / \mathrm{L}$, respectively (Table 2). According to WHO (2008), the maximum acceptable concentration of TDS in groundwater for domestic purposes is $500 \mathrm{mg} / \mathrm{L}$. All the groundwater samples have TDS values well within the permissible limit of WHO (2008). On the other hand, as per the TDS classification (Fetter 1990), the collected all groundwater samples belonged to fresh water (TDS $<1000 \mathrm{mg} / \mathrm{L}$ ) categories.

Average total hardness was 304.23 and $302.281 \mathrm{mg} / \mathrm{L}$ for shallow and deep tube wells, respectively (Table 2).

Table 2 Statistical summary of physicochemical and microbial parameters of groundwater of Rajshahi City and their comparison with the WHO and Bangladesh standards for drinking water

\begin{tabular}{|c|c|c|c|c|}
\hline Parameters & $\begin{array}{l}\text { Shallow tubewells } \\
\text { Mean } \pm \text { SD }\end{array}$ & $\begin{array}{l}\text { Deep tubewells } \\
\text { Mean } \pm \text { SD }\end{array}$ & BD DWS (Bangladesh 2009) & WHO DWS (2011) \\
\hline Temp. $\left({ }^{\circ} \mathrm{C}\right)$ & $27.39 \pm 0.68$ & $27.2 \pm 0.54$ & - & - \\
\hline $\mathrm{pH}$ & $6.91 \pm 0.18$ & $7.0 \pm 0.14$ & $6.5-8.5$ & $6.5-8.5$ \\
\hline $\mathrm{EC}(\mu \mathrm{S} / \mathrm{cm})$ & $445.44 \pm 49.41$ & $454.98 \pm 52.47$ & - & - \\
\hline TH (mg/L) & $304.24 \pm 29.75$ & $302.3 \pm 54.49$ & 500 & 100 \\
\hline TDS (mg/L) & $297.44 \pm 49.7$ & $241.65 \pm 21.7$ & - & 500 \\
\hline TSS (mg/L) & $162.94 \pm 32.63$ & $247.00 \pm 63.01$ & 10 & - \\
\hline TS (mg/L) & $293.51 \pm 142.53$ & $269.73 \pm 31.9$ & - & - \\
\hline $\mathrm{HCO}_{3}(\mathrm{mg} / \mathrm{L})$ & $245.30 \pm 29.59$ & $188.36 \pm 2.28$ & 100 & 100 \\
\hline $\mathrm{Cl}(\mathrm{mg} / \mathrm{L})$ & $55.315 \pm 9.9$ & $44.9 \pm 9.7$ & 600 & 200 \\
\hline $\mathrm{NO}_{3}(\mathrm{mg} / \mathrm{L})$ & $1.60 \pm 0.48$ & $1.67 \pm 0.51$ & 10 & 45 \\
\hline $\mathrm{SO}_{4}(\mathrm{mg} / \mathrm{L})$ & $38.76 \pm 5.2$ & $36.6 \pm 2.92$ & 400 & 200 \\
\hline $\mathrm{Na}(\mathrm{mg} / \mathrm{L})$ & $23.12 \pm 1.96$ & $22.77 \pm 2.24$ & 200 & 200 \\
\hline $\mathrm{K}(\mathrm{mg} / \mathrm{L})$ & $5.66 \pm 0.57$ & $5.63 \pm 0.52$ & 12 & - \\
\hline $\mathrm{Mg}(\mathrm{mg} / \mathrm{L})$ & $27.02 \pm 2.13$ & $26.22 \pm 1.66$ & 35 & 50 \\
\hline $\mathrm{Ca}(\mathrm{mg} / \mathrm{L})$ & $78.35 \pm 7.6$ & $78.54 \pm 0.38$ & 75 & 75 \\
\hline $\mathrm{Fe}(\mathrm{mg} / \mathrm{L})$ & $3.1 \pm 0.64$ & $2.23 \pm 5.72$ & $0.3-1$ & 0.3 \\
\hline $\mathrm{Mn}(\mathrm{mg} / \mathrm{L})$ & $1.47 \pm 0.78$ & $2.2 \pm 0.74$ & 0.1 & 0.01 \\
\hline $\mathrm{Zn}(\mathrm{mg} / \mathrm{L})$ & $0.19 \pm 0.07$ & $0.18 \pm 0.08$ & 5 & 3 \\
\hline $\mathrm{Cu}(\mathrm{mg} / \mathrm{L})$ & $0.08 \pm 0.06$ & $0.39 \pm 0.42$ & 1 & 1 \\
\hline As (mg/L) & $0.017 \pm 0.01$ & $0.012 \pm 0.01$ & 0.05 & 0.01 \\
\hline $\mathrm{Cd}(\mathrm{mg} / \mathrm{L})$ & $0.014 \pm 0.01$ & $0.016 \pm 0.01$ & - & 0.003 \\
\hline $\mathrm{Pb}(\mathrm{mg} / \mathrm{L})$ & $1.167 \pm 0.14$ & $1.12 \pm 0.13$ & 0.05 & 0.01 \\
\hline TC (CFU/100 mL) & $8.8 \pm 8.1$ & $3.7 \pm 2.2$ & 0 & 0 \\
\hline $\mathrm{FC}(\mathrm{CFU} / 100 \mathrm{~mL})$ & $0.63 \pm 0.8$ & $0.11 \pm 0.33$ & 0 & 0 \\
\hline
\end{tabular}


Dufor and Becker (1964) classification, about 93.6\% of samples belong to very hard type and the rest of hard type water. The hardness of $150-300 \mathrm{mg} / \mathrm{L}$ and above may cause kidney problems and kidney stone formation, as it causes unpleasant taste and reduces the ability of soap to produce lather (Jain 1998).

The concentration of bicarbonate in shallow and deep tube wells was found with an average of 245.30 and $188.36 \mathrm{mg} / \mathrm{L}$, respectively (Table 2). In general, $\mathrm{HCO}_{3}{ }^{-}$ has no adverse health effects on human health; even it exceeds $300 \mathrm{mg} / \mathrm{L}$ in the drinking water. However, it should not exceed $300 \mathrm{mg} / \mathrm{L}$ in the potable water, as it may lead to kidney stones in the presence of the higher concentration of $\mathrm{Ca}$, especially in dry climatic regions. The elevated values suggest that the groundwater system was open to soil $\mathrm{CO}_{2}$, resulting from the decay of organic matter and root respiration, which in turn, combines with rainwater to form bicarbonate (Matthess and Harvey 1982).

The chloride mean concentration was 55.315 and $44.901 \mathrm{mg} / \mathrm{L}$, respectively for shallow and deep tube wells (Table 2). It is the second most abundant element after $\mathrm{HCO}_{3}{ }^{-}$ion. The concentration of $\mathrm{Cl}^{-}$in groundwater samples from 17.43 to $111 \mathrm{mg} / \mathrm{L}$ (not shown in Table 2), may be attributed to industrial, domestic wastes, poor sanitary conditions, leaching from upper soil layers in dry climates, natural geochemical activities.

The average concentrations of $\mathrm{SO}_{4}{ }^{2-}$ were found to be 38.75 and $36.60 \mathrm{mg} / \mathrm{L}$ for shallow and deep tube wells, respectively (Table 2). The lower sulfate content indicates that the study area was not an industrial city as the high content of sulfate indicates anthropogenic sources and industrial process, etc.

$\mathrm{NO}_{3}{ }^{-}$was present with a mean of 1.598 and $1.665 \mathrm{mg} / \mathrm{L}$ for shallow and deep tube wells, respectively (Table 2). The concentration of $\mathrm{NO}_{3}{ }^{-}$was found at a slightly higher range in the deep tube wells compared to the shallow wells and both were bellowed the guideline (WHO 2011). In natural conditions, the concentration of $\mathrm{NO}_{3}{ }^{-}$does not exceed $10 \mathrm{mg} / \mathrm{L}$ in the water (Cushing et al. 1973). Another researcher, Chauhan et al. (2009) illustrated the lower concentration of $\mathrm{NO}_{3}{ }^{-}$, indicates the lack of bacterial mediated reactions in the study.

\section{Major cations in groundwater}

The mean concentration of $\mathrm{Na}^{+}$in the area was found with an average of 23.11 and $22.76 \mathrm{mg} / \mathrm{L}$ for shallow and deep tube wells, respectively (Table 2). There is no standard set for sodium in water. However, USEPA (1994) has recommended that sodium levels in drinking water not exceed 20 milligrams per liter $(\mathrm{mg} / \mathrm{L})$. Groundwater of the area was safe for drinking with reference to the mean concentration of $\mathrm{Na}^{+}$. Tripathi et al. (2007) illustrated that the
Ganges alluvial sediments consist of feldspars in the range from 6 to 12 at different locations along its course. The results suggest that $\mathrm{Na}^{+}$was derived from weathering of halite and feldspar rocks sources in this area.

The analysis results show that concentration of $\mathrm{K}^{+}$in shallow and deep tube wells were found with a mean 5.66 and $5.626 \mathrm{mg} / \mathrm{L}$, respectively (Table 2) and all samples were within the permissible limit.

The analysis results show that $\mathrm{Ca}^{2+}$ concentration of the shallow and deep tube wells was with a mean of 78.35 and $78.54 \mathrm{mg} / \mathrm{L}$, respectively (Table 2). Kozisek (2004) stated that about $70 \%$ of groundwater samples exceeded the maximum permissible limit $(300 \mathrm{mg} / \mathrm{L})$. The results illustrate that $\mathrm{Mg}^{2+}$ concentration in the shallow and deep tube wells water samples with a mean value were 27.02 and $26.22 \mathrm{mg} / \mathrm{L}$, respectively (Table 2). All of the samples were within the permissible limit for WHO (2011) and Bangladesh standard.

\section{Heavy metals in groundwater}

The average iron concentration in the shallow and deep tube wells of the area were 3.1 and $2.23 \mathrm{mg} / \mathrm{L}$, respectively (Table 2). Maximum samples contained high iron concentration than the permissible limit $(0.3-1.0 \mathrm{mg} / \mathrm{L})$ of (Bangladesh Standard). The average iron concentration of the groundwater (shallow and deep) samples was found to be $2.66 \mathrm{mg} / \mathrm{L}$, which was about 9 and 3 times higher than the WHO and Bangladesh drinking water standard, respectively. Hem (1991) illustrated that a high iron concentration in groundwater may be due to the presence of iron minerals in the soils and/or weathered materials favorable for reduction of ferric iron into ferrous iron in the circulating groundwater. The higher presence of iron drinking water causes harm and makes the teeth and nail black, and weak, stickiness of hair.

The study results show that Mn concentrations of shallow and deep tube wells were found with a mean of 1.47 and $2.2 \mathrm{mg} / \mathrm{L}$, respectively (Table 2). All the samples exceed the permissible limit $0.10 \mathrm{mg} / \mathrm{L}$ for Bangladesh Drinking Water Standard (BD DWS) and $0.01 \mathrm{mg} / \mathrm{L}$ for WHO standard. Similar results were reported by the National Hydro-geochemical Survey where the report illustrated that three-quarters of the 3534 wells surveyed in 61 out of 64 districts exceeded the BD DWS $(0.1 \mathrm{mg} / \mathrm{L})$ for Mn (BGS and WaterAid 2001). A report showed that Mn produced a brownish color in laundered clothing, left black particles on fixtures, and with iron affecting the taste of beverages, including coffee and tea. High intakes of $\mathrm{Mn}$ through both inhalational exposure and drinking water have been shown to be toxic (IMFNB 2002).

Average concentrations of $\mathrm{Pb}$ in shallow and deep tube wells water sample were 1.167 and $1.122 \mathrm{mg} / \mathrm{L}$, 
respectively (Table 2) which exceeds the permissible limit $(0.05 \mathrm{mg} / \mathrm{L})$. An average of high $\mathrm{Pb}$ concentration was found in aquifer soil samples indicating the reason of $\mathrm{Pb}$ in shallow and deep tube wells water. The analysis results illustrate that $\mathrm{Pb}$ presence in the groundwater of Rajshahi City follows in the order: post-monsoon $>$ monsoon $>$ premonsoon season (not shown in Table). $\mathrm{Pb}$ ion is toxic and also considered a probable human carcinogen. Thus, $\mathrm{Pb}$ intake via drinking water involves a potential health hazard.

The concentrations of $\mathrm{Zn}, \mathrm{Cu}$ and $\mathrm{Cd}$ in the shallow tube wells water sample with a mean ionic concentration were $0.189,0.076$ and $0.013 \mathrm{mg} / \mathrm{L}$, respectively. An average of $\mathrm{Zn}, \mathrm{Cu}$ and $\mathrm{Cd}$ in deep tube wells water sample was 0.176 , 0.393 and $0.016 \mathrm{mg} / \mathrm{L}$ (Table 2). $\mathrm{Zn}, \mathrm{Cu}$ and $\mathrm{Cd}$ concentrations were found to be low in three seasons and were not exceeded the WHO and BD DWS due to low content of these minerals in the aquifer soil in the area (data were not shown in Table 2). The amount of highly toxic metals $\mathrm{Cd}$ was found well below the prescribed limits for both types of water samples.

AS concentration in the shallow and deep tube wells water samples were with an average of 0.017 and $0.012 \mathrm{mg} / \mathrm{L}$, respectively (Table 2). Most of the postmonsoon water samples exceeded the WHO permissible limits of $0.01 \mathrm{mg} / \mathrm{L}$, and a few samples exceeded the Bangladesh permissible limits of $0.05 \mathrm{mg} / \mathrm{L}$. Acute exposure of As can cause nausea, vomiting, diarrhea, muscle cramps, salivation, sensory disturbances, liver injury, renal failure and kidney disease. Ingesting arsenic increases the risk of skin cancer and tumors of the bladder, kidney, liver and lung (Smith et al. 1992). The study results showed that the water quality of the deep tube wells was comparatively better than that of the shallow tube wells suggesting for use as drinking water in the study area.

\section{Total coliform (TC) and fecal coliform (FC) in groundwater}

The total coliform (TC) bacteria were found with a mean of $8.8 \pm 8.1$ and $0.63 \pm 0.8 \mathrm{CFU} / 100 \mathrm{~mL}$ for the shallow and deep tube wells, respectively. Whereas the fecal coliform (FC) bacteria for both water was $3.7 \pm 2.2$ and $0.11 \pm 0.33 \mathrm{CFU} / 100 \mathrm{~mL}$, respectively (Table 2). Elevated concentrations of TC were found in most of the ground water samples, but few samples exceeded FC values for the WHO and Bangladesh drinking water standard.

\section{Hydrogeochemical facies and water types}

The piper diagram shows a graphical representation of the concentrations of ions in a water sample and the separate ternary plots shown the cations and anions (Piper 1944). The major cations and anions were plotted in the two base triangles of the Piper diagram, and they show the relative concentrations of the major cations $\left(\mathrm{Ca}^{2+}, \mathrm{Mg}^{2+}, \mathrm{Na}^{+}\right.$and $\mathrm{K}^{+}$) and anions $\left(\mathrm{HCO}_{3}{ }^{-}, \mathrm{Cl}^{-}, \mathrm{NO}_{3}{ }^{-}\right.$and $\mathrm{SO}_{4}{ }^{2-}$ ) (Piper 1944). The ternary anion diagram relating $\mathrm{HCO}_{3}{ }^{-}, \mathrm{SO}_{4}{ }^{2-}$ and $\mathrm{Cl}^{-}$shows that most of the groundwater samples contained a high amount of $\mathrm{HCO}_{3}{ }^{-}$and plotted points cluster toward the alkalinity apex with secondary trended toward $\mathrm{Cl}^{-}$and $\mathrm{SO}_{4}{ }^{2-}$. The proportion of $\mathrm{HCO}_{3}{ }^{-}$and $\mathrm{SO}_{4}{ }^{2-}$ in the water reflected the relative dominance of the two major sources of protons (carbonation and sulfide oxidation) during chemical weathering. Pandey et al. (2001) suggested that a carbonic acid weathering process was the major proton producer in waters where a relatively high ratio of $\mathrm{HCO}_{3}{ }^{-} /\left(\mathrm{HCO}_{3}{ }^{-}+\mathrm{SO}_{4}{ }^{2-}\right)$ was found. In this study, the ratio of $\mathrm{HCO}_{3}{ }^{-} /\left(\mathrm{HCO}_{3}{ }^{-}+\mathrm{SO}_{4}{ }^{2-}\right)$ was very high (0.94) which indicates that a mostly carbonic acid weathering process involved in the groundwater geochemistry. Therefore, most of the shallow and deep tube wells water samples analyzed during the pre-monsoon, monsoon and post-monsoon fall in the field of $\mathrm{CaHCO}_{3}$ type for in the quadrilateral diagram (Fig. 2).

\section{Geo-chemistry of ground water}

\section{Groundwater geochemical processes}

The abundance and distribution of elemental ions such as $\mathrm{Ca}, \mathrm{Mg}, \mathrm{Na}, \mathrm{K}, \mathrm{HCO}_{3}{ }^{-}, \mathrm{SO}_{4}{ }^{2-}$ and $\mathrm{Cl}^{-}$in the water are dependent on erosion and chemical weathering of the rocks in the catchments or source area. Water soluble $\mathrm{Na}^{+}$and $\mathrm{K}^{+}$ions are considered to be generated from weathering of Feldspar and montmorillonite. The mineralogical origin in the Ganges alluvium is the main reason for higher concentrations of the above cations in the groundwater (Vinod 2012). Moreover, several reports illustrated that cation exchange processes and industrial activities also contribute to high $\mathrm{Ca}, \mathrm{Mg}, \mathrm{Na}$ and $\mathrm{K}$ ions concentrations in the study area (Naidu et al. 1985; Singh et al. 1997, 2006). On the one hand, the silicate minerals that comprise most rocks did not react readily with most groundwater. On the other hand, carbonate minerals did react quite readily with water, and they played an important role in the evolution of many ground waters.

\section{Carbonate weathering and dissolution}

The study results illustrate that $\mathrm{Ca}$ and $\mathrm{Mg}$ ions were dominant among the cations. Most of the samples found below the ratio line 2 and above 1.5, indicating the presence of calcite weathering (Fig. 3) as stated by Maya and Loucks (1995). Only a few samples that lie above the ratio line 2 indicated the effect of silicate minerals. The study results illustrate that the overall chemical composition of 
Fig. 2 Hydro-chemical facies of groundwater in Rajshahi City area in the Piper diagram, water type: $\mathrm{Ca}-\mathrm{HCO}_{3}$

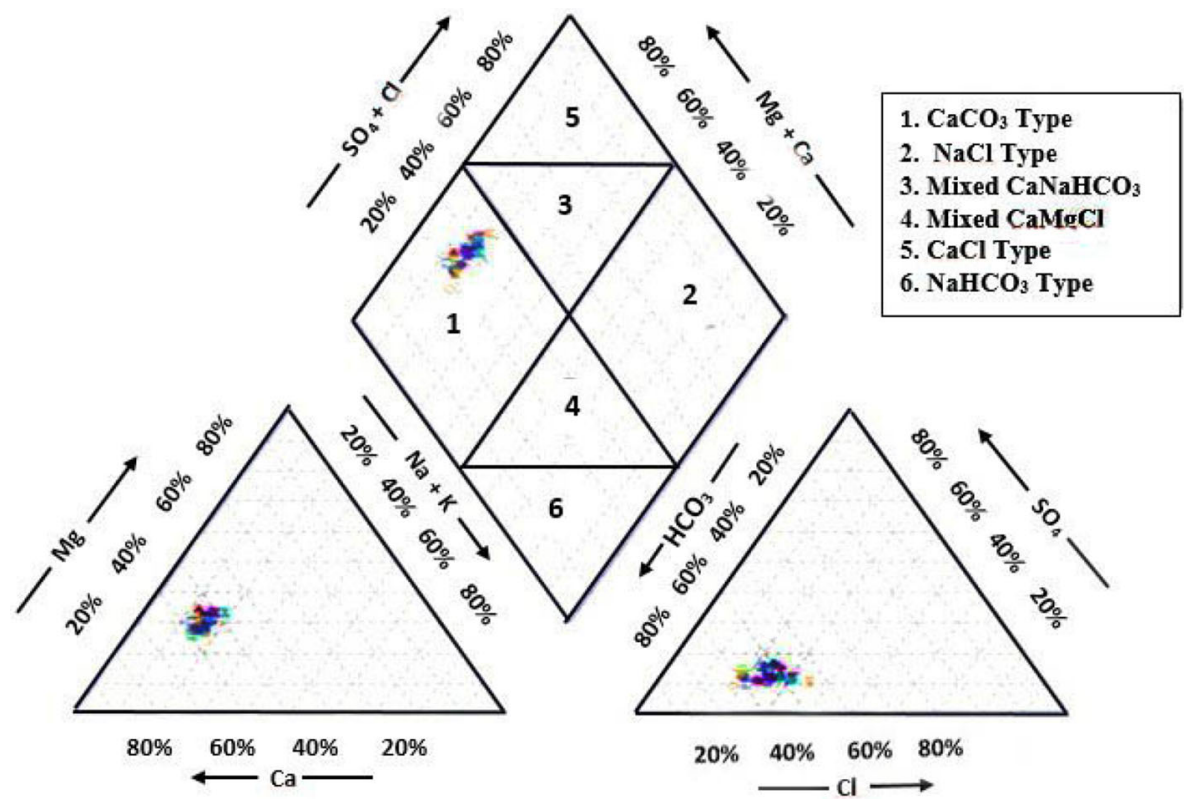

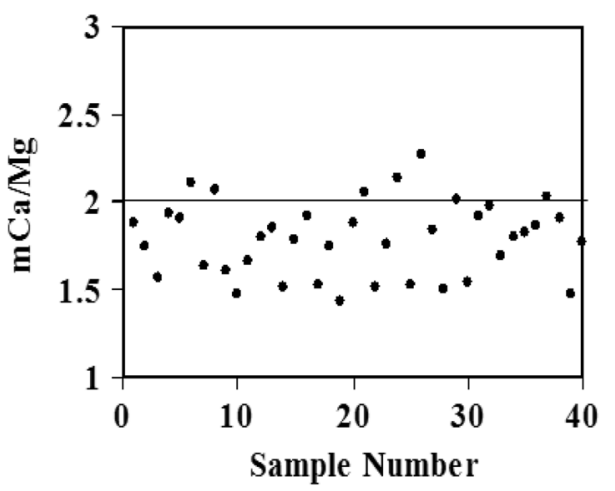

Fig. 3 The scatter diagram of $\mathrm{Ca} / \mathrm{Mg}$ molar ratio. $\mathrm{Ca} / \mathrm{Mg}=1$ dolomite weathering, $\mathrm{Ca} / \mathrm{Mg}>1$ Calcite weathering, $\mathrm{Ca} / \mathrm{Mg}>2$ silicate weathering

the groundwater in the study area was a result of calcite weathering and it could be carbonic acid.

Moreover, a scatter diagram is shown in Fig. 4 illustrate that most of the groundwater samples fall below the 1:2 line and along the 1:1 equiline and far below 1:4 line indicating calcite weathering as suggested by Garrels and Mackenzie (1971).

Another evidence of calcite weathering is shown in Fig. 5 where a good positive correlation between the sum of $\mathrm{Mg}^{2+}$ and $\mathrm{Ca}^{2+}$ versus $\mathrm{HCO}_{3}{ }^{-}$indicates that these ions were generally derived from the dissolution of carbonate minerals (Fig. 5).

The statistical parameters of the computed $\mathrm{pCO}_{2}$ values for the water samples are shown in Table 3 . The results showed that $\mathrm{pCO}_{2}$ values of shallow tube wells in the monsoon and

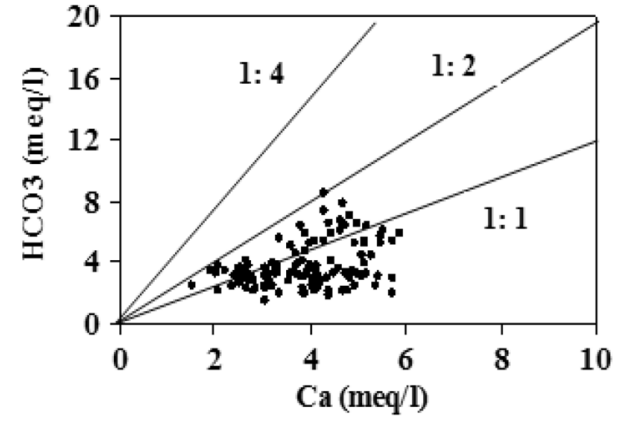

Fig. 4 The scatter diagram of $\mathrm{Ca}^{2-}$ versus $\mathrm{HCO}_{3}{ }^{2-}$ around 1:2 line indicates that carbonic acid is the agent in the weathering of calcite

post-monsoon and deep tube wells in the monsoon seasons were greater than that of the atmosphere pressure 0.03 (atm).

The results suggest that the waters are supersaturated with carbonate minerals as the dissolved $\mathrm{CO}_{2}$ gas pressure of the waters was higher. A similar observation was made by Drever (1997) related to the present findings.

\section{Groundwater quality}

The analysis results showed that the mean concentration of cations was observed in the order: $\mathrm{Ca}>\mathrm{Mg}>$ $\mathrm{Na}>\mathrm{K}>\mathrm{Fe}>\mathrm{Mn}>\mathrm{Pb}>\mathrm{Zn}>\mathrm{Cu}>$ As $\quad$ (total) $>\mathrm{Cd}$ while for the anions, $\mathrm{HCO}_{3}{ }^{-}>\mathrm{Cl}^{-}>\mathrm{SO}_{4}{ }^{2-}>\mathrm{NO}_{3}{ }^{-}$ (Table 2). The concentration of TH, TDS, $\mathrm{HCO}_{3}{ }^{-}, \mathrm{NO}_{3}{ }^{-}$, $\mathrm{Ca}, \mathrm{Fe}, \mathrm{Zn}, \mathrm{Cu}, \mathrm{Pb}$, and As (total) was found to be higher during post-monsoon compared to pre-monsoon, whilst $\mathrm{K}$, $\mathrm{Mg}, \mathrm{Cd}$, and $\mathrm{Cl}$ were found higher during pre-monsoon and monsoon (not shown in Table 2). The high concentration 
Fig. $5 \mathrm{Ca}^{+} \mathrm{Mg}$ versus $\mathrm{HCO}_{3}{ }^{-}$ indicate these ions are generally derived from the dissolution of carbonate minerals

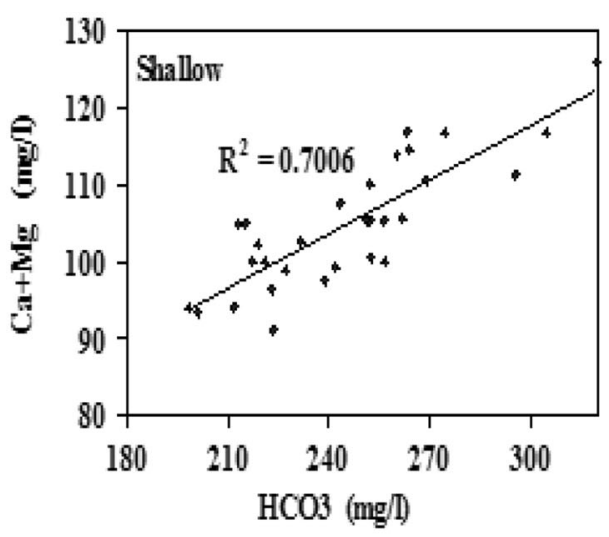

Table 3 Partial pressure of $\mathrm{CO}_{2}$ (determine by Aquachem Software)

\begin{tabular}{lllllllll}
\hline $\mathrm{PCO}_{2}(\mathrm{~atm})$ & \multicolumn{2}{l}{ Shallow tubewells } & & \multicolumn{2}{l}{ Deep tubewells } & & \multicolumn{3}{c}{ Atmospheric $\mathrm{CO}_{2}$} \\
\cline { 2 - 3 } & Pre-monsoon & Monsoon & Post-monsoon & & Pre-monsoon & Monsoon & Post-monsoon \\
\hline & 0.0112 & 0.05173 & 0.08655 & 0.0041 & 0.04581 & 0.013 & 0.03 \\
\hline
\end{tabular}

of heavy metals in the water has a serious threat to human health. An elevated level of $\mathrm{Pb}$ and $\mathrm{Mn}$ concentrations were found in almost all of the analyzed samples indicating unsuitability for drinking and cooking purposes.

\section{Conclusions}

The analysis results revealed that the groundwater of the studied area was hard to very hard, slightly alkaline to neutral $\mathrm{pH}$ in nature. The TDS falls under fresh water categories. The $\mathrm{HCO}_{3}{ }^{-}$concentration exceeded the permissible limit. The concentration of $\mathrm{Na}, \mathrm{K}, \mathrm{Mg}, \mathrm{Cu}, \mathrm{Zn}$ ions were below the detectable limit in most of the wells samples but $\mathrm{Ca}, \mathrm{Fe}, \mathrm{Mn}, \mathrm{As}, \mathrm{Pb}$ ions exceeded the safe limit. The major hydrochemical facies was a $\mathrm{CaHCO}_{3}$ type identified using the Piper trilinear diagram. The analysis results indicated that the carbonate weathering due to calcite dissolution was the major geochemical process contributing to the cations and anions of the aquifer water. The concentration of calcium, iron, manganese, arsenic and lead ions were found far above the permissible limit in most of the shallow tube wells water samples. The analysis results show that the mean concentration of cations and anions followed the order: $\mathrm{Ca}>\mathrm{Mg}>\mathrm{Na}>\mathrm{K}>$ $\mathrm{Fe}>\mathrm{Mn}>\mathrm{Pb}>\mathrm{Zn}>\mathrm{Cu}>\mathrm{As} \quad$ (total) $>\mathrm{Cd}$ and $\mathrm{HCO}_{3}{ }^{-}>\mathrm{Cl}^{-}>\mathrm{SO}_{4}{ }^{2-}>\mathrm{NO}_{3}{ }^{-}$, respectively. The concentration of most of the physic-chemical parameters was found to be higher during the post-monsoon compared to the pre-monsoon, whilst $\mathrm{K}, \mathrm{Mg}, \mathrm{Cd}$, and $\mathrm{Cl}$ were found higher during the pre-monsoon and monsoon. The concentration of physicochemical constituents in the water samples were compared with the WHO and Bangladesh Drinking Standards to know the drinking water suitability of the study area. The study results revealed that the water quality of the area was moderately contaminated with heavy metals and is threatening human health. The overall results of the study reveal that the groundwater was not suitable for human consumption without adequate treatment, especially for $\mathrm{Pb}, \mathrm{Mn}$ and $\mathrm{As}$ to ensure the quality required for safe drinking water.

Open Access This article is distributed under the terms of the Creative Commons Attribution 4.0 International License (http:// creativecommons.org/licenses/by/4.0/), which permits unrestricted use, distribution, and reproduction in any medium, provided you give appropriate credit to the original author(s) and the source, provide a link to the Creative Commons license, and indicate if changes were made.

\section{References}

Adams VD (1991) Water and Wastewater examination manual. Lewis Publishers Inc, USA

Albarède F (2003) Geochemistry: an introduction. Cambridge University Press, Cambridge, P.1. ISBN 0-521-81468-5

APHA (2005) Standard methods for the examination of water and wastewater, 21st edn. American Public Health Association/ American Water Works Association/Water Environment Federation, Washington

Bangladesh (2009) Bangladesh National Drinking Water Quality Survey of 2009. Bangladesh Bureau of Statistic, Planning Division, Ministry of Planning, Government of Bangladesh. Website: https://www.unicef.org/bangladesh/BNDWQS_2009_ web.pdf

Banglapedia (2006) National encyclopedia of Bangladesh. http://en. wikipedia.org/wiki/Rajshahi. Accessed 25 May 2017 
BBS (Bangladesh Bureau of Statistics) (2005) Compendium of environment statistics of Bangladesh. Government of the People's Republic of Bangladesh, Dhaka

BGS and WaterAid (2001) Groundwater quality: Bangladesh. British Geological Survey and WaterAid Bangladesh

Chauhan VS, Nickson RT, Chauhan D, Iyengar L, Sankararamakrishnan N (2009) Ground water geochemistry of Ballia district, Uttar Pradesh, India and mechanism of arsenic release. Chemosphere 75(2009):83-91. doi:10.1016/j.chemosphere.2008.11.065

Cushing EM, Kantrowitz IH, Taylor KR (1973) Water resources of the Delmarva Peninsular. US Geol Surv Prof Pap 822:58

Drever JI (1988) The geochemistry of natural waters, 2nd edn. Prentice Hall Englewood Cliff, New York, p 437

Drever JI (1997) The geochemistry of natural waters, 2nd edn. Prentice-Hill, New York, p 379

Dufor CN, Becker E (1964) Public water supplies of the 100 largest cities in the US. Geol Surv Water Supply Pap 1812:364

Fetter CW (1990) Applied hydrogeology. Mirril Publ. Co., USA

Frengstad B, Banks D, Siewers U (2001) The chemistry of Norwegian groundwater. IV. The $\mathrm{pH}$-dependence of element concentrations in crystalline bedrock groundwaters. Sci Total Environ 227:101-117

Garrels RM, Mackenzie FT (1971) Evolution of sedimentary rocks. WW Norton, New York

Gupta S, Dandele PS, Verma MB, Maithani PB (2009) Geochemical assessment of groundwater around Macherla-Karempudi area, Guntur District, Andhra Pradesh. J Geol Soc India 73:202-212

Hem JD (1986) Study and interpretation of the chemical characteristics of natural water: U.S. Geological Survey Water-Supply Paper 2254, p 263

Hem JD (1991) Study and interpretation of the chemical characteristics of natural waters, book 2254, 3rd edn. Scientific Publishers, Jodhpur

IMFNB (Institute of Medicine Food and Nutrition Board) (2002) Dietary reference intakes: vitamin A, vitamin K, arsenic, boron, chromium, copper, iodine, iron, manganese, molybdenum, nickel, silicon, vanadium and zinc. National Academy Press, Washington

Jaime Gárfias N, Arroyo R Aravena (2010) Hydrochemistry and origins of mineralized waters in the Puebla aquifer system, Mexico. Environ Earth Sci 59(8):1789-1805

Jain PK (1998) Hydrology and quality of groundwater around Hirapur district—a case study of protozoic rocks. Pollut Res 17(1):91-94

Jalali M (2006) Chemical characteristics of groundwater in parts of mountainous region, Alvand, Hamadan, Iran. Environ Geol $51: 433-446$

Johnson CC (1979) Land application of water-an accident waiting to happen. Groundwater

Kozisek F (2004) Health risks from drinking demineralised water. World Health Organization, Geneva, 2004. Available from: http://www.who.int/water_sanitation_health/dwq/ nutrientschap12.pdf. Accessed 27 May 2017

Loukola-Ruskeeniemi K, Uutela A, Tenhola M, Paukola T (1998) Environmental impact of metalliferous black shales at Talvivaara in Finland, with indication of lake acidification 9000 years ago. J Geochem Explor 64:395-407

Loukola-Ruskeeniemi K, Kantola M, Halonen T, Seppanen K, Henttonen P, Kallio E (2003) Mercury bearing black shales and human $\mathrm{Hg}$ intake in eastern Finland: impact and mechanisms. Environ Geol 43:283-297

Matthess G, Harvey JC (1982) The properties of groundwater. Wiley, New York

Maya AL, Loucks MD (1995) Solute and isotopic geochemistry and groundwater flow in the Central Wasatch Range, Utah. J Hydrol 172:31-59

Naidu AS, Mowati TC, Somayajulu BL, Rao KS (1985) Characteristics of clay minerals in the bed loads of major river of India.
Mitteilungen aus dem Geologische-Palaontologischen Instituts der Universitat Hamburg 58:559-568

Nickson RT, McArthur JM, Shrestha B, Kyaw-Nyint TO, Lowry D (2005) Arsenic and other drinking water quality issues, Muzaffargarh District. Pak Appl Geochem pp 55-68

Pandey SK, Singh AK, Hasnain SI (2001) Hydrochemical characteristics of melt water draining from Pindari glacier, Kumon Himalaya. J Geol Soc India 57:519-527

Piispanen R, Nykyri T (1997) Acidification of groundwater in waterfilled gravel pits-a new environmental and geomedical threat. Environ Geochem Health 19:111-126

Piper AM (1944) A graphic procedure in the geochemical interpretation of water analyses. Trans Am Geophys Union 25:914-928

Pitt R, Clark S, Field R (1999) Groundwater contamination potential from storm water infiltration practices. Urban Water 1:217-236

Sastri JCV (1994) Groundwater chemical quality in river basins, hydrogeochemical modeling. Lecture notes-Refresher course, School of Earth Sciences, Bharathidasan Univ., Tiruchirappalli, Tamil Nadu, India

Singh M, Ansari AA, Muller G, Singh IB (1997) Heavy metals in the freshly deposited sediments of the Gomati river (a tributary of the Ganga river): effect of human activities. Environ Geol 29:246-252

Singh KP, Malik A, Mohan D, Singh VK, Sinha S (2006) Evaluation of groundwater quality in Northern Indo-Gangetic alluvium region. Environ Monit Assess 112:211-230

Singh VK, Bikundia DS, Sarswat A, Mohan D (2012) Groundwater quality assessment in the village of Lutfullapur Nawada, Loni, District Ghaziabad, Uttar Pradesh, India. Environ Monit Assess 184:4473-4488. doi:10.1007/s10661-011-2279-0

Smith AH, Hopenhayn-Rich C, Bates M, Goeden HM, HertzPicciotto I, Duggan HM, Wood R, Kosnett MJ, Smith MT (1992) Cancer risks from arsenic in drinking water. Environ Health Perspect 97:259-267

Sreedevi PD (2004) Groundwater quality of Pageru River basin, Cuddapah District, Andhra Pradesh. J Geol Soc India 64:619-636

Subba Rao N (2006) Seasonal variation of groundwater quality in a part of Guntur district, Andhra Pradesh, India. J Environ Geol 49:413-429

Subba Rao N, Surya Rao P (2009) Major ion chemistry of groundwater in a river basin: a study from India. Environ Earth Sci 61(4):757-775

Tripathi JK, Ghazanfari P, Rajamani V, Tandon SK (2007) Geochemistry of sediments of the Ganges alluvial plains: evidence of large-scale sediment recycling. Quatern Int 159:119-130

USEPA (1994) Healthy drinking waters. https://ag.umass.edu/sites/ ag.umass.edu/files/fact-sheets/pdf/sodium.pdf

WHO (2008) Guidelines for drinking-water quality, 3rd edn, Incorporating the First and Second, Addenda, Vol 1, Recommendations. Internet website: http://www.who.int/water_sanitation health/dwq/gdwq3rev/en/. Accessed 12 July 2011

WHO (2011) Guidelines for drinking-water quality, 4th Edition. ISBN 978924154815 1. Website: http://apps.who.int/iris/ bitstream/10665/44584/1/9789241548151_eng.pdf

WHO, Regional Office for South-East Asia (2002) Country health system profile: Bangladesh. Available from: http://www.who.int/ gho/countries/bgd/country_profiles/en/. Accessed 25, 27 May 2017

Wikipedia (2015) Water supply and sanitation in Bangladesh. Website: https://en.wikipedia.org/wiki/Water_supply_and_ sanitation_in_Bangladesh. Last access 27 May 2017

\section{Publisher's Note}

Springer Nature remains neutral with regard to jurisdictional claims in published maps and institutional affiliations. 